\title{
A Importância do Mercado Latino-Americano e da Competição Chinesa para o Desempenho recente das Exportações Brasileiras de Produtos Manufaturados
}

\section{The Importance of Latin American market and Chinese Competition for the recent Performance of Brazilian Manufactured Goods Exports}

\author{
Marta dos Reis Castilho* \\ Kaio Glauber Vital da Costa** \\ Júlia Ferreira Torracca***
}

\begin{abstract}
Resumo: As exportações brasileiras de produtos manufaturados apresentam uma especialização geográfica bem demarcada, tanto em termos de volume quanto de composição e grau de sofisticação dos produtos. Para os produtos manufaturados, a América Latina se tornou o principal mercado desde os anos 1990, além de revelar algum grau de articulação produtiva entre as economias. Porém, ao longo dos anos 2000, a parcela de mercado de manufaturados do Brasil na região vem se reduzindo devido à perda de competitividade dos produtos brasileiros associada ao acirramento da concorrência chinesa na região e à erosão das preferências comerciais do Brasil na América Latina. O presente trabalho analisa o desempenho e as perspectivas das exportações brasileiras de manufaturados segundo seus principais destinos usando indicadores de comércio (de market share e de similaridade das pautas exportadoras), que sistematizam as informações acerca da especialização da pauta exportadora brasileira e da articulação produtiva do Brasil com seus principais parceiros. Tal análise evidencia a importância do comércio regional para as exportações de manufaturados do país, apesar da redução do market share do Brasil nesses mercados. A fim de aprofundar o entendimento das causas para essa evolução recente, são examinados as perdas e ganhos das exportações de manufaturados do Brasil na Aladi em relação à China, utilizando-se uma versão modificada da metodologia de constant market share (CMS).
\end{abstract}

Palavras-chave: Comércio internacional. Produtos manufaturados. Integração regional. Aladi. China.

Abstract: Brazilian exports of manufactured goods have a high geographical specialization, both concerning trade volume, sectoral composition and product sophistication. Latin

\footnotetext{
* $\quad$ Professora do Instituto de Economia da Universidade Federal do Rio de Janeiro (UFRJ). Pesquisadora do Grupo de Indústria e Competitividade (GIC-IE/UFRJ). Pesquisadora convidada no ICEI-Universidad Complutense de Madrid - Programa PVEX/CAPES (Proc. 88881.172830/201801).E-mail: castilho@ie.ufrj.br

** Professor do Instituto de Economia da Universidade Federal do Rio de Janeiro (UFRJ). Pesquisador do Grupo de Indústria e Competitividade (GIC-IE/UFRJ).E-mail: kaio.costa@ ie.ufrj.br

*** Professora da Faculdade de Economia da Universidade Federal Fluminense (UFF). Pesquisadora do Grupo de Indústria e Competitividade (GIC-IE/UFRJ).E-mail: jtorracca@gmail.com
} 
America became since the 90s the main market for Brazilian manufacturing exports, besides having increased the degree of productive articulation. However, during the 2000s, Brazil has been losing its market share in the region due to the loss of Brazilian goods competitiveness face to the deepening of the Chinese competition and the erosion of regional trade preferences. This paper analyzes the performance and perspectives of Brazilian manufactured exports using trade indicators (market share and similarities of exports structure indicators) that capture the exports specialization and the productive integration of Brazil according to its main trade partners. Such an analysis shows the relevance of the regional market for the Brazilian manufactured products, despite the loss of Brazil's market share in Latin American countries. In order to understand the causes of this recent trajectory, this paper examines the gains and losses for Brazil regarding the Chinese competition in Latin American Integration Association (LAIA) countries, adopting a modified version of the constant market share (CMS).

Keywords: International trade. Manufactured goods. Regional integration. LAIA. China.

JEL Classification: F02; F14; F15.

\section{1 lntrodução}

As exportações brasileiras têm uma especialização geográfica e setorial bastante demarcada. O tipo dos produtos exportados, o grau de sofisticação e diversificação da pauta exportadora, entre outras características, são bastante distintos segundo os mercados de destino. Essas diferenças se acentuaram ainda mais durante os anos 2000, que foi um período marcado por um forte crescimento das exportações e também por mudanças importantes em seu perfil.

Essa diferença de estrutura das exportações brasileiras, segundo seus principais parceiros comerciais, é observada desde os anos 1990. Tal característica é evidente não somente em termos do peso de produtos manufaturados no total exportado, mas também em termos do tipo e da sofisticação dos produtos manufaturados. Durante os anos 1990, as exportações brasileiras apresentaram baixo crescimento em virtude basicamente da sobrevalorização da moeda e do baixo dinamismo da economia mundial. Ainda assim, devido, sobretudo, à realização e reativação dos acordos com os parceiros latino-americanos, houve uma diversificação geográfica da pauta de exportações brasileiras, com ganho de importância dos parceiros latino-americanos.

Já nos anos 2000, observa-se, mais acentuadamente a partir de 2002, um boom das exportações conjugado com importantes alterações em sua composição geográfica, mas também setorial. Os produtos agrícolas e minerais aumentaram suas participações no total exportado pelo país em detrimento dos produtos manufaturados, e a diversificação de mercados de exportações aumentou por causa, em grande medida, do crescimento das exportações brasileiras para a China. Esses movimentos refletiram, por um lado, o ciclo de elevação dos preços internacio- 
nais das commodities e, por outro lado, a concomitante perda de competitividade dos produtos manufaturados brasileiros nos diversos mercados (CARNEIRO, 2012). O crescimento da economia chinesa foi outro fator relevante para as mudanças observadas na pauta exportadora, influenciando não somente as exportações de produtos básicos de forma positiva, mas também as exportações de manufaturados de forma indireta. Estas se viram, por um lado, ameaçadas pela competição chinesa em terceiros mercados e, por outro lado, estimuladas por uma maior demanda proveniente dos países exportadores de produtos básicos também estimulados pelo "apetite" chinês por matérias-primas (HIRATUKA et al., 2012; MEDEIROS, 2010).

O presente artigo analisa a especialização setorial e geográfica das exportações brasileiras de 1990 a 2013. Tal análise evidencia as importantes diferenças de composição dos produtos brasileiros segundo os seus destinos em suas diversas dimensões (setorial, em termos de grau de sofisticação e de integração produtiva). Nessa comparação, as especificidades da pauta de exportações para a América Latina ficam evidentes e mostram que os países da região são o mercado mais relevante para o Brasil no que se refere às exportações de manufaturados, em particular, daqueles de maior grau de sofisticação tecnológica. A análise também mostra que, nos anos mais recentes, as exportações brasileiras de produtos manufaturados vêm perdendo participação justamente em seu mercado mais importante, a América Latina. Essa perda está associada a diversos fatores, mas o acirramento da concorrência chinesa na região tem sido, em grande parte, responsável pela perda nos mercados mais dinâmicos, do ponto de vista da sofisticação tecnológica e produtiva.

A posição favorável do Brasil nos mercados latino-americanos de produtos manufaturados, em especial naqueles de maior grau de sofisticação, resulta, em parte, das preferências comerciais dos acordos tarifários existentes na região, no âmbito do Mercosul e da Associação Latino-Americana de Integração (Aladi). Essas preferências asseguraram, até recentemente, diferenças de preços nos mercados latino-americanos favoráveis aos produtos manufaturados brasileiros. Elas também possibilitaram a formação de estratégias empresariais que produziram algum tipo de articulação produtiva com os países do Mercosul, ou seja, uma incipiente integração produtiva regional (CASTILHO, 2012).

Esse último aspecto é de dupla relevância. Por um lado, a fragmentação internacional da produção levou a uma reordenação mundial da produção, fortemente caracterizada pela formação de cadeias regionais de produção e valor - mais do que cadeias globais de valor (BALDWIN, 2012). O Brasil e seus vizinhos sul-americanos se encontram, por diversas razões, alijados das cadeias existentes na América do Norte, na Europa e na Ásia. Por outro lado, a especialização dos países da América Latina em manufaturas baseadas em recursos naturais os colo- 
ca como fornecedores de insumos para os demais países, localizando-os no início de muitas cadeias produtivas.

Uma opção que se coloca para o Brasil de integração dinâmica nesse cenário, então, se apoia no aprofundamento da incipiente integração produtiva entre os países da América Latina. Uma maior integração produtiva na região pode gerar efeitos dinâmicos positivos que terminem por ampliar a demanda pelos produtos manufaturados brasileiros (além dos benefícios diretos para os países vizinhos), a exemplo do que ocorre no sudeste asiático (BAUMANN, 2010; MEDEIROS, 2010; CHEN; LOMBAERDE, 2011; FLORES; VAILLANT, 2011). A integração produtiva regional pode não somente fazer parte de uma estratégia de aumento da competitividade internacional da indústria brasileira, mas também se constituir em um fator de coesão política e econômica da região.

Neste trabalho, primeiramente analisa-se a pauta brasileira de exportações de manufaturados desagregada segundo seus principais parceiros, considerando-se as dimensões mencionadas anteriormente (setorial, sofisticação tecnológica e integração produtiva), que fundamentam a constatação do maior dinamismo do mercado latino-americano em face de outros parceiros comerciais brasileiros. Em outras palavras, avalia-se o grau de sofisticação dos produtos - comparando-se a pauta de exportações brasileira com a estrutura de exportações da Organização para a Cooperação e Desenvolvimento Econômico (OCDE) por meio do índice de similaridade - e também em que medida existe algum grau de articulação produtiva com os diversos parceiros - distinguindo-se o comércio por estágios de produção. Em seguida, investiga-se uma das principais causas para a redução recente de participação do Brasil nos mercados de manufaturados da região: o acirramento da concorrência chinesa. Para isso, utiliza-se o modelo de constant market share (CMS) em sua versão modificada, que permite associar as perdas (ou ganhos) de um país a ganhos (ou perdas) de outros parceiros.

Este trabalho está estruturado em cinco seções, além desta introdução: a seção 2 mostra a evolução das exportações brasileiras desde a década de 1990 até o ano de 2013, com especial ênfase nas exportações de produtos manufaturados; a seção 3 avalia o grau de sofisticação da pauta de exportações, utilizando uma comparação com a pauta de exportações da OCDE e também o grau de integração dos fluxos bilaterais nas redes globais de comércio e produção, a partir da importância de bens de capital e de partes e componentes; a seção 4 analisa a competição da China no mercado latino-americano de produtos manufaturados; a seção 5 apresenta estimativas de ganhos e perdas de exportações de manufaturados do Brasil nos países da Aladi relativamente aos principais parceiros comerciais da região; por fim, a seção 6 traz as considerações finais. 


\section{Evolução e Especialização das Exportações Brasileiras de Manufaturados}

As exportações brasileiras apresentaram forte crescimento nos anos 2000 devido, em grande parte, aos efeitos diretos e indiretos do aumento dos preços internacionais das commodities. ${ }^{1}$ Além do crescimento do valor das exportações devido aos maiores preços, também houve uma expansão significativa do quantum de commodities exportado. Isso ocorreu mesmo em um contexto de valorização do câmbio, cujo efeito negativo sobre as exportações foi mais do que compensado pelo efeito positivo da alta dos preços internacionais desses produtos. ${ }^{2}$ Como consequência desse movimento, a composição da pauta de exportações brasileiras se alterou de forma significativa. Segundo os dados da Secex, os produtos básicos respondiam por aproximadamente metade das exportações brasileiras em 2013, mesma participação observada em 1978 (nesses dois anos, as exportações de produtos básicos representavam $47 \%$ do total exportado). Os produtos manufaturados perderam, em compensação, cerca de 20 pontos percentuais de participação nas exportações totais desde o ano 2000, quando as exportações desses bens apresentaram seu melhor desempenho (correspondendo a 59\% do total exportado). ${ }^{3}$

Ao longo dos anos 2000, observou-se um aumento da participação das manufaturas baseadas em recursos naturais no total exportado pelo país. Esse processo, conhecido na literatura como "reprimarização da pauta de exportadora", teve

$1 \quad$ Sobre os diversos fatores que impulsionaram tal movimento, vale mencionar aqueles associados à demanda-como o aumento da procura por commodities relacionada ao crescimento econômico asiático e, em particular, chinês, a financeirização dos mercados de commodities e a desvalorização do dólar relativamente a outras moedas (CASTILHO, 2011). Serrano (2013) aponta razões associadas à oferta, sendo algumas específicas a determinados mercados (como o controle da oferta pela Organização dos Países Exportadores de Petróleo - OPEP - , a estagnação da capacidade produtiva de determinados setores minerais ou o aumento da produção de biocombustíveis) e outras mais gerais (como o chamado "nacionalismo dos recursos minerais", que induziu os governos a tentarem extrair maiores rendas da exploração dos recursos naturais).

2 Um indicador da medida em que a evolução do câmbio e dos preços internacionais se compensou no período consiste no indicador de rentabilidade das exportações, calculado pela Fundação Centro de Estudos do Comércio Exterior (Funcex), que corresponde à taxa de câmbio nominal $(\mathrm{R} \$ / \mathrm{US} \$)$ corrigida pela relação entre o índice de preço das exportações e o índice de custo de produção (GUIMARÃES et al., 2010). No período compreendido entre 2003 e 2011, quando a taxa de câmbio real, segundo o Ipeadata, atingiu seu nível mais baixo (em julho de 2011), o indicador de rentabilidade das exportações totais brasileiras acusou queda até 2006 e, após, mostrou relativa estabilidade. Os setores que apresentaram evolução mais favorável foram os setores relacionados a minérios e petróleo, além de produtos alimentícios, agricultura, produção florestal e vestuário. A explicação para tal evolução (com exceção de vestuário) é que o aumento dos preços das exportações, puxados pela alta internacional das commodities, compensou a pressão negativa do câmbio real sobre a rentabilidade das exportações desses produtos. Os produtos manufaturados, em geral, apresentaram evolução da rentabilidade mais desfavorável do que os produtos minerais e agrícolas.

3 Esse processo foi por vezes identificado como um dos sintomas do processo de desindustrialização. Para uma discussão sobre desindustrialização, ver Oreiro e Feijó (2010) e Palma (2005). Para uma ampla revisão da literatura sobre o tema, ver Morceiro (2012). 
como contrapartida a perda de importância das manufaturas não baseadas em recursos naturais nas exportações totais do país (CUNHA et al., 2011; MORCEIRO, 2012). Porém, essa constatação deve ser qualificada em três direções. Em primeiro lugar, deve-se distinguir perda de dinamismo e perda de importância (share) dos manufaturados na pauta de exportações. Em segundo lugar, esse processo de reprimarização tem uma dimensão geográfica importante, refletindo as diferenças bem marcadas em termos de composição das exportações segundo os parceiros comerciais. Em terceiro lugar, o ganho de importância das exportações de bens primários afasta ainda mais o Brasil das redes globais de produção e valor.

O valor das exportações brasileiras de produtos manufaturados apresentou uma taxa média de crescimento entre 2000 e 2013 de 8,8\% a.a. Essa taxa é inferior àquela observada para as exportações totais brasileiras (10,5\% a.a.), que foi fortemente influenciada pelo desempenho das exportações agrícolas e minerais, cujo crescimento médio foi de $18 \%$ a.a. Porém, essa taxa supera aquela observada para o comércio mundial de produtos manufaturados, cujo valor se expandiu a uma taxa média de 6,3\% a.a. entre 2000 e 2013. De fato, o desempenho das exportações brasileiras superou o desempenho do comércio mundial tanto para manufaturados, quanto para produtos agrícolas e minerais (ver Gráfico 1). Por consequência, o market share do Brasil apresentou uma recuperação ao longo dos anos 2000, após a retração ocorrida na década de 1990.

Gráfico 1 - Evolução do valor das exportações brasileiras e mundiais totais de produtos manufaturados: 2000-2014 (base: $2000=100$ )

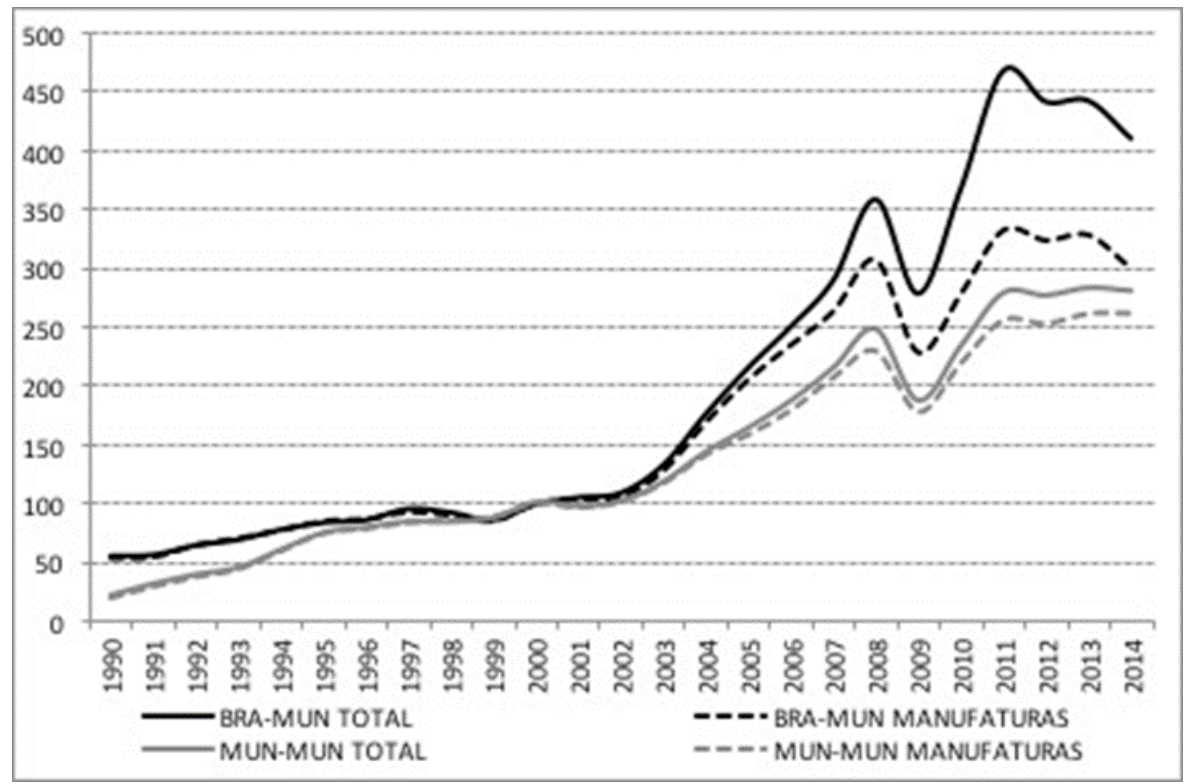

Fonte: Elaboração própria a partir de dados da United Nations Statistics Division (2019). 
O perfil geográfico das exportações de manufaturados brasileiros possui padrões bastante distintos (ver Gráfico 2). Pode-se identificar três diferentes grupos de países, segundo o peso dos manufaturados e sua composição entre os parceiros comerciais brasileiros. No primeiro grupo, que reúne os países latino-americanos e alguns países em desenvolvimento africanos ou do Oriente Médio, o peso dos manufaturados nas exportações totais é elevado. No segundo grupo, encontra-se o perfil oposto, em que predominam bens agrícolas e minerais, com baixo grau de elaboração industrial. Nesse estão economias como a China e outros países asiáticos (como Coreia do Sul e Japão, por exemplo). O terceiro grupo apresenta um perfil misto (em termos de peso dos manufaturados nas exportações brasileiras para aqueles destinos), mas cujo volume das exportações de manufaturados é relevante para o Brasil (trata-se basicamente de Estados Unidos e União Europeia - UE).

Gráfico 2 - Principais destinos das exportações brasileiras totais e de manufaturados (em \% do total)

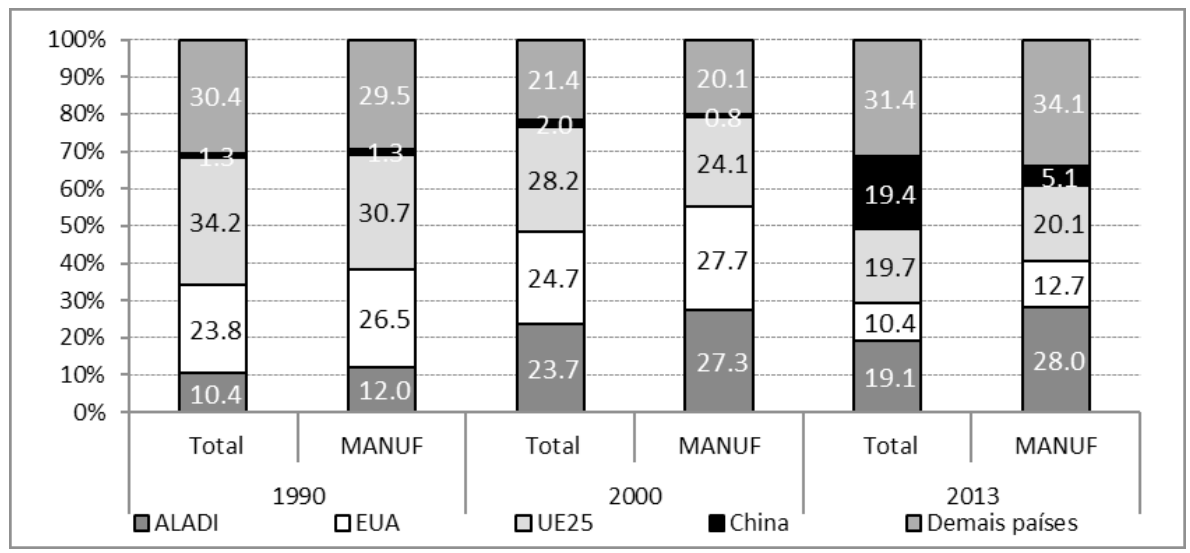

Fonte: Elaboração própria a partir de dados da United Nations Statistics Division (2019).

Os países da América Latina se consolidaram como os principais mercados dos produtos manufaturados brasileiros desde a década de 1990. Em 2013, os países da Aladi absorveram $28 \%$ das exportações brasileiras de produtos manufaturados não baseados em recursos naturais. A UE, ${ }^{4}$ apesar de ser um dos principais compradores de produtos primários brasileiros, representa $20 \%$ dos produtos manufaturados brasileiros. Os Estados Unidos correspondem atualmente, após importante retração de suas compras junto ao Brasil, 12,7\% do total de exportações de manufaturados. De fato, observa-se uma expressiva queda da participação dos Estados Unidos ao longo dos anos 2000, tanto para o conjunto de produtos, quan-

4 Utilizou-se a classificação da União Europeia composta por 25 países, apresentada pela UN Comtrade. 
to para os manufaturados, que corresponderam a $76 \%$ das exportações brasileiras para os Estados Unidos em 2013.

Com relação à China, que se consolidou como um dos principais destinos das exportações brasileiras no período pós-crise de 2008, sua demanda esteve muito concentrada em produtos primários, principalmente em soja e minério de ferro. O forte crescimento das exportações de produtos primários (crescimento de $35,9 \%$ a.a. entre 2000 e 2013) para a China acabou por encobrir o crescimento das exportações de manufaturados do Brasil para esse país, que cresceu $26 \%$ a.a. no mesmo período. Contudo, apesar desse crescimento ser superior ao das exportações brasileiras totais de manufaturados ( $9,5 \%$ a.a.), seu ponto de partida é extremamente baixo em termos de quantum exportado. Como resultado, o peso da China como destino das exportações totais contrasta fortemente com seu peso nas exportações de manufaturados (19,4\% contra 5,1\% em 2013).

Outra característica importante das exportações brasileiras de manufaturados ao longo dos anos 2000 foi o processo de diversificação geográfica. O grupo referente aos demais destinos (ver Gráfico 2) passou de 20\%, em 2000, para 34\%, em 2013 (em 1990, esse percentual era de 29,5\%). Nesse grupo, alguns países se destacaram, ainda que suas participações individuais continuem relativamente baixas. ${ }^{5}$ É interessante notar que a influência da China nas exportações brasileiras se acentuou na segunda metade dos anos 2000 , em particular no período pós-crise, quando ela se tornou o primeiro parceiro comercial do país. Em 2013, a China respondeu por 19,4\% das exportações totais brasileiras. Das exportações para aquele país, $72 \%$ consistiam apenas de dois produtos: soja em grão e minério de ferro (37\% e 35\%, respectivamente). Somente as exportações desses dois produtos para a China representam 13,7\% das exportações totais brasileiras. Ou seja, o grau de concentração das exportações brasileiras para a China é extremamente elevado, de modo que o comércio bilateral mostra um forte padrão norte-sul.

Em função dessas características do comércio bilateral Brasil-China, parte relevante do fenômeno de reprimarização está associado ao comércio com esse país. Para se medir esse efeito China, simulou-se qual seria o perfil das exportações brasileiras para um "mundo sem China" (ver Gráfico 3). Os resultados mostram que a reprimarização seria menos intensa e o peso dos produtos manufaturados nas exportações para esse mundo hipotético seria mais próximo daquele observado nas exportações para o mercado norte-americano, por exemplo.

5 As exceções ficaram em 2013 com o Panamá, que absorveu cerca de 3\% das exportações brasileiras em virtude de operações com sondas de petróleo, além de Hong Kong, Japão e Rússia, cujas participações foram de cerca de $2 \%$ nesse ano. 


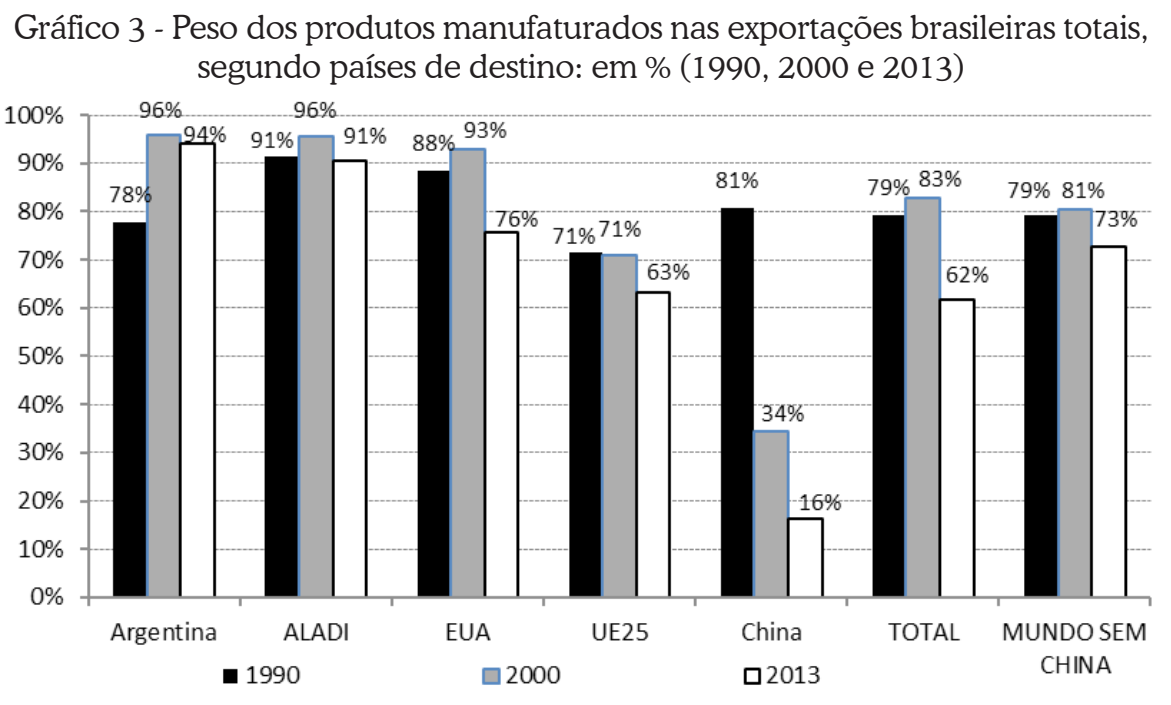

Fonte: Elaboração própria a partir de dados da United Nations Statistics Division (2019).

\section{A Sofisticação da Pauta Exportadora do Brasil e a Integração nas Redes Globais de Produção}

A diferença do grau de sofisticação dos bens exportados pelo Brasil, segundo seus diferentes parceiros, fica evidente a partir da comparação das pautas de exportações por destino com a pauta de exportações totais da OCDE, tomada como referência em termos de sofisticação das exportações. O índice de similaridade foi calculado originalmente por Finger e Kreinin (1979) para medir a similaridade das exportações entre dois países ou regiões no mercado mundial. ${ }^{6}$ O Gráfico 4 apresenta os resultados do índice de similaridade utilizado para estimar a diferença na composição das exportações brasileiras por destino em comparação às exportações de países desenvolvidos que possuem uma pauta, em geral, associada a bens com maior conteúdo tecnológico. Para isso, utiliza-se o índice de similaridade, que tem a seguinte forma funcional:

$$
\operatorname{ISE}_{\mathrm{ijt}}^{\mathrm{k}}=\sum_{\mathrm{k}=1}^{\mathrm{n}} \min \left(\mathrm{S}_{\mathrm{ixt}}^{\mathrm{k}} ; \mathrm{S}_{\mathrm{jwt}}^{\mathrm{k}}\right)
$$

6 Silva, Batista e Drummond (2011) comparam o desempenho dos BRICs (Brasil, Rússia, Índia e China) com o da OCDE e mostram que, para as exportações totais brasileiras, houve um aumento no índice de similaridade com a pauta exportadora do grupo de países de 2000 até 2006, caindo em seguida até 2011. 
O termo ISE $E^{k}{ }_{j \mathrm{t}}$ representa o índice de similaridade das exportações do país $i$ (Brasil) e do país j (OCDE), $\mathrm{s}_{\mathrm{ixt}}^{\mathrm{k}}$ é a participação do produto $k$ na pauta de exportação do país i (Brasil) para o mercado $x$ (mundo, Aladi, Argentina, UE-25 e Estados Unidos) no tempo $t$ e $\mathrm{s}_{\text {jwt }}^{\mathrm{k}}$ a participação do produto $k$ na pauta de exportação do país j (OCDE) para $w$ (mundo). O índice varia entre e, e, quanto mais próximas estão as pautas exportadoras dos dois países em análise (ou quanto maior for a participação de produtos exportados simultaneamente pelos dois países), mais próximo de 1 estará o índice de similaridade. ${ }^{7}$

O Gráfico 4 mostra de que maneira a estrutura da pauta de exportações brasileiras se assemelha com aquela observada para os países da OCDE de acordo com diferentes destinos. A similaridade das pautas é mais forte para os países da Aladi. Para essa região, cerca de $60 \%$ produtos manufaturados exportados pelo Brasil também estão presentes na pauta de exportações da OCDE. O grau de similaridade é intermediário para os Estados Unidos e para a UE-25, atestando um grau de sofisticação também intermediário e bastante superior ao nível observado nas exportações para a China. Para este país, o valor das exportações brasileiras, quando há coincidência com a pauta da OCDE, é inferior a 10\%.

Gráfico 4 - Evolução do grau de similaridade da pauta de exportações de manufaturados do Brasil (por destino) relativa à OCDE

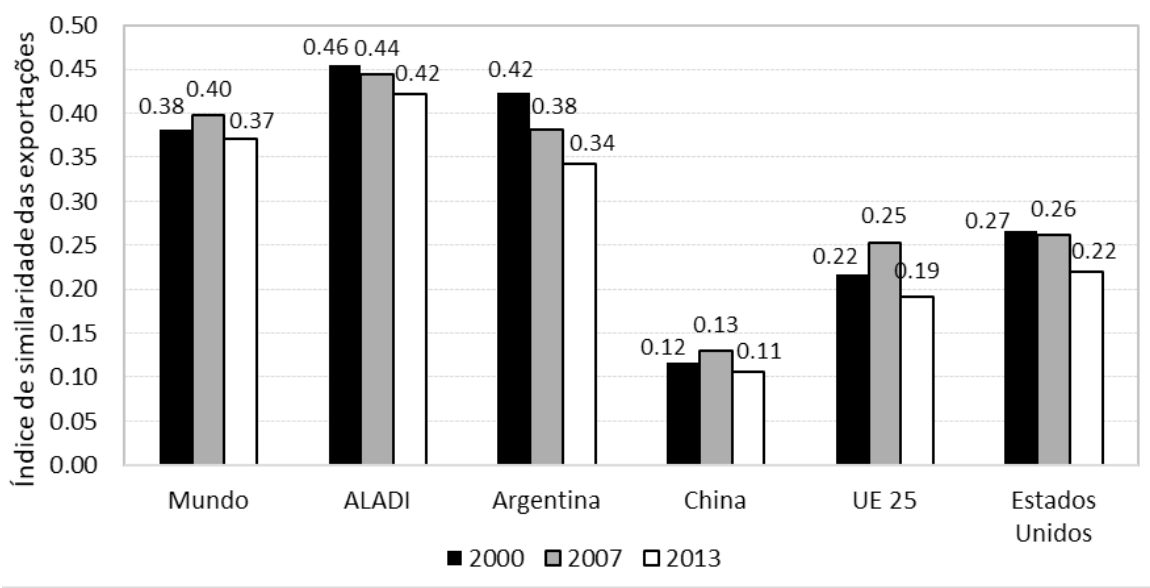

Fonte: Elaboração própria a partir de dados da United Nations Statistics Division (2019).

Ademais, observa-se, no Gráfico 4, que a estrutura das exportações brasileiras se distanciou progressivamente daquela da OCDE. Ou seja, o conjunto de

$7 \quad$ Os dados utilizados estão desagregados a quatro dígitos da industrial standart international classification (ISIC), revisão dois. A escolha de tal grau de desagregação se deve ao fato de que esse índice tende a ser progressivamente menor quanto maior o grau de desagregação. Por isso, um grau demasiado baixo pode sugerir uma falsa similaridade. 
produtos exportados simultaneamente pelo Brasil e pela OCDE vem perdendo importância nas exportações brasileiras. Esse crescente distanciamento entre as pautas brasileiras e as da OCDE ocorre nas exportações para todos os parceiros do Brasil analisados, ainda que com intensidades diversas e por diferentes razões.

No caso das exportações brasileiras para a Aladi e Argentina, a diminuição da similaridade ocorreu basicamente pelo ganho de importância de equipamentos de transporte, que passou a ter nas exportações do Brasil com seus vizinhos um peso superior ao observado nas exportações da OCDE. Para os demais mercados, o aumento do peso das commodities manufaturadas nas exportações brasileiras é a principal razão para o distanciamento relativo à pauta de exportações da OCDE. Evidentemente, no caso chinês, a participação desses produtos no total exportado pelo Brasil é superior - desde o início do período - àquela observada nas exportações para a UE e os Estados Unidos.

Essa proxy para o grau de sofisticação da pauta - o grau de similaridade relativa às exportações dos países da OCDE - reitera as diferenças já assinaladas das pautas de exportações brasileiras segundo o destino e a importância do mercado latino-americano para as exportações de manufaturados brasileiros. A evolução do índice de similaridade, no entanto, mostra também que a reprimarização das exportações teve como resultado um distanciamento entre a pauta de produtos exportados pelo Brasil vis-à-vis àquela observada pelos países da OCDE, e, nesse caso, uma redução do grau de sofisticação das exportações brasileiras.

\subsection{A Baixa Integração da Manufatura Brasileira nas Redes Globais de Produção e Valor e a Incipiente Articulação Produtiva Regional}

As diferenças regionais que se manifestaram na composição setorial das exportações brasileiras também revelaram outra característica da inserção internacional brasileira no período recente: sua baixa inserção nas redes globais de produção e valor. Como apontado por Feenstra (1998), Milberg (2004), Baldwin (2012), United Nations Conference on Trade and Development (2013) e Comisión Económica para América Latina y el Caribe (2014), a fragmentação dos processos produtivos permitiu a reorganização da produção em nível mundial e acabou por aprofundar as redes internacionais de produção e valor. A partilha dos processos produtivos provocou o deslocamento de suas diferentes etapas em diferentes países, de acordo com as vantagens de custo (principalmente custos de mão de obra) de cada país e por meio de diversos arranjos institucionais entre as firmas (outsourcing, investimento direto estrangeiro, entre outros). ${ }^{8}$

$8 \quad$ Para Baldwin (2012), esse fenômeno é explicado como o "second unbundling", ou seja, menores custos de transporte e comunicação, resultantes da revolução nas tecnologias de comunicação e informação na década de 1980, permitiram a separação física de várias partes ou tarefas que compõem um processo produtivo. 
Essas redes são particularmente dinâmicas na Ásia e se tornaram uma referência para a análise dos benefícios que podem advir da integração dos países a tais redes. Porém, como também tem sido mencionado na literatura sobre a inserção dos países em desenvolvimento nas cadeias de valor e de produção, a possibilidade de participação - sobretudo, uma participação virtuosa para o país - depende de diversos fatores. A participação como fornecedor de partes e componentes ou como montador do bem final não assegura ganhos para os países que assim se inserem. ${ }^{9}$ Medeiros (2010) alerta que nem todos os países participantes das cadeias de valor internacionais conseguem extrair os mesmos benefícios, podendo diferir de acordo com o posicionamento do país dentro das cadeias. Os benefícios dependem, em muitos casos, da capacidade do país de se apropriar dos ganhos advindos da localização em determinada etapa do processo produtivo, sendo essa capacidade associada ao aprendizado e à mudança tecnológica (MEDEIROS, 2010). Além desses aspectos - o tipo de inserção dos países nas redes é relevante -, existem fatores histórico-institucionais e características idiossincráticas dos países que condicionam sua participação em tais redes.

Nesse sentido, o contraste entre a inserção do Brasil, assim como dos demais países da América Latina (com exceção do México) nas cadeias globais de valor e aquela dos países asiáticos é em grande parte explicado pela importância dos setores intensivos em recursos naturais na pauta exportadora latino-americana. Esses setores, além de baseados na exploração de recursos naturais, se caracterizam por processos de produção contínuos e com baixa possibilidade de fragmentação. Além disso, como chamam atenção Veiga e Rios (2008), a construção da base industrial da região antecede a emergência do processo de fragmentação internacional da produção, imprimindo diversas características a essas indústrias que são determinantes de sua articulação com o mercado internacional, tais como forte verticalização das atividades dentro das fronteiras nacionais. Essas características mantiveram-se predominantes apesar das mudanças trazidas pela liberalização comercial e pela entrada de investimentos estrangeiros na década de 1990.

Pérez (2012) argumenta que a dificuldade enfrentada pela América Latina para o desenvolvimento de indústrias de montagem decorre da distribuição inicial de fatores, que difere fortemente entre a América Latina e a Ásia, com consequências sobre a especialização das economias, sua inserção nas cadeias globais de valor e também sobre as distribuições de renda nas duas regiões. Rocha (2012) argumenta, no entanto, que é possível promover um upgrading da base industrial da região apoiada nos setores intensivos em recursos naturais, pois “[...] há possibilidade de aprendizado e desenvolvimento a partir das indústrias de processo [...]” (ROCHA, 2012, p. 64, tradução nossa).

9 Ver United Nations Conference on Trade and Development (2013), Whittaker et al. (2010) e Milberg e Winkler (2013). 
A América Latina e o Brasil, em particular, encontram-se alijados de tais cadeias, tornando o fortalecimento da incipiente articulação produtiva regional uma medida economicamente benéfica para todos os países participantes. Como mostrado por Chen e Lombaerde (2011) e Baumann (2011), a China desempenha um papel importante na transmissão do dinamismo de sua economia e de suas exportações para os países menores de seu entorno geográfico mediante as suas relações intraindustriais. A integração produtiva regional garante que os benefícios obtidos pela China, por meio de seus superávits junto ao ocidente, sejam repassados para seus parceiros comerciais da região.

No caso da América Latina, esse fenômeno não se observa: o Brasil, que poderia desempenhar esse papel de líder e, assim, garantir, inclusive, um mercado mais dinâmico para seus produtos, mantém superávits com a maioria dos países da região. Aliás, isso ocorre também com os demais países grandes da Aladi - Argentina e México também são superavitários com a região. Conforme aponta Baumann (2010,2011), os déficits sistemáticos dos países pequenos atestam uma distribuição desigual dos ganhos (diretos e indiretos) da integração, que não são compensados nem por instrumentos de transferência entre os países (políticas regionais ou mecanismos compensatórios) nem por ganhos decorrentes de uma maior integração produtiva. Tais ganhos resultariam de uma demanda por parte dos países maiores de produtos manufaturados provenientes dos países menores, tais como insumos, partes e componentes. Nesse contexto, os países menores passariam a ser mais beneficiados pelos ciclos de crescimento nas economias maiores. Pereira (2015) percebe a integração produtiva na América Latina como outro benefício, o de atrair investimentos para projetos regionais, cujos benefícios seriam compartilhados pelo Brasil com seus vizinhos. ${ }^{10}$

As informações a seguir corroboram as características mencionadas acerca da inserção do Brasil nas redes internacionais de valor e produção. Elas basicamente dizem respeito ao peso de bens intermediários e de capital nos fluxos de comércio. Essa é uma das possíveis formas de mensuração do grau de integração das economias em tais redes e se justifica pelo fato desses bens estarem no centro do processo produtivo. ${ }^{11}$ A produção e a comercialização desses bens por um determinado país indicam sua inserção em cadeias de produção de bens finais, que podem estar internacionalmente distribuídas. Vale assinalar, ainda, que esses bens

10 Para a autora, acordos comerciais mais profundos do Brasil com seus vizinhos poderiam estimular a integração produtiva regional caso o país aceitasse ampliar o escopo dos acordos existentes na região (e também se investisse no aumento da produtividade de sua manufatura).

11 Como apontado por Meng, Fang e Yamano (2012), a participação nas cadeias globais de valor e a fragmentação internacional da produção também podem ser medidas através dos seguintes indicadores: especialização vertical ou conteúdo importado contido nas exportações e conteúdo doméstico de um determinado país presente nas exportações de países terceiros. 
intermediários muitas vezes carregam em si uma boa parte da tecnologia contida nos produtos finais.

Utiliza-se aqui a análise por estágio de produção, elaborada por Lemoine e Ünal-Kesenci (2002) a partir da broad economic classification (BEC) da Organização das Nações Unidas, ${ }^{12}$ que evidencia a natureza da especialização de um país (ver Quadro 1). Para os bens intermediários, permite a distinção entre os bens intermediários semiacabados (insumos industriais básicos, como lingotes de aço) e os bens intermediários compostos por peças e componentes. Pelas características assinaladas anteriormente, um comércio ativo de partes e componentes e de bens de capital indica uma maior participação do país nas redes internacionais.

Quadro 1 - Classificação dos bens segundo os estágios de produção com base nas categorias econômicas amplas (broad economic categories)

\begin{tabular}{|c|c|c|}
\hline Estágio de produção & BEC & Descrição BEC \\
\hline \multirow{3}{*}{ Bens primários (EP1) } & BEC-21 & Insumos industriais básicos, não especificados. \\
\hline & BEC-31 & Combustíveis e lubrificantes processados. \\
\hline & & $\begin{array}{l}\text { Alimentos e bebidas básicos destinados principalmente } \\
\text { à indústria. }\end{array}$ \\
\hline \multirow{3}{*}{$\begin{array}{l}\text { Bens intermediários } \\
\text { semiacabados (EP2) }\end{array}$} & BEC-22 & Insumos industriais processados, não especificados. \\
\hline & BEC-121 & Alimentos e bebidas processados destinados à indústria. \\
\hline & BEC-32 & Combustíveis e lubrificantes processados. \\
\hline \multirow{2}{*}{$\begin{array}{l}\text { Bens intermediários: } \\
\text { partes e componentes } \\
\text { (EP3) }\end{array}$} & & $\begin{array}{l}\text { Peças e acessórios de bens de capital (exceto material } \\
\text { de transporte). }\end{array}$ \\
\hline & BEC-53 & Peças e acessórios de material de transporte. \\
\hline \multirow{2}{*}{$\begin{array}{l}\text { Bens finais: bens de } \\
\text { capital (EP4) }\end{array}$} & BEC-41 & Bens de capital (exceto material de transporte). \\
\hline & & $\begin{array}{l}\text { Material de transporte, peças e acessórios: outros, desti- } \\
\text { nados à indústria. }\end{array}$ \\
\hline \multirow{7}{*}{$\begin{array}{l}\text { Bens finais: bens de } \\
\text { consumo (EP5) }\end{array}$} & & $\begin{array}{l}\text { Material transporte, peças e acessórios: veículos auto- } \\
\text { motores de passageiros. }\end{array}$ \\
\hline & BEC-61 & Bens de consumo duráveis não especificados. \\
\hline & BEC-62 & Bens de consumo semiduráveis não especificados. \\
\hline & BEC-63 & Bens de consumo não duráveis não especificados. \\
\hline & BEC-112 & $\begin{array}{l}\text { Alimentos e bebidas básicos, não processados, destina- } \\
\text { dos principalmente ao consumo doméstico. }\end{array}$ \\
\hline & BEC-122 & $\begin{array}{l}\text { Alimentos e bebidas, processados, destinados principal- } \\
\text { mente ao consumo doméstico. }\end{array}$ \\
\hline & BEC-522 & $\begin{array}{l}\text { Material de transporte, peças e acessórios: outros não } \\
\text { destinados à indústria. }\end{array}$ \\
\hline
\end{tabular}

Nota: EP = estágio de produção. Fonte: Lemoine e Ünal-Kesenci (2002).

12 Essa classificação distingue os produtos por seu uso final. 
Para o Brasil, o comércio de partes e componentes é relativamente baixo - quando comparado com economias como a China e o México, por exemplo ${ }^{13}$ - e manifesta, ainda, a exemplo do comércio em geral, diferenças significativas segundo os parceiros. Primeiramente, o Brasil importa mais bens de capital e intermediários do que exporta, gerando um déficit comercial relevante relativamente à corrente de comércio desses bens (ver Tabela 1). ${ }^{14} \mathrm{O}$ Brasil absorve esses bens para produção de bens que são voltados, sobretudo, para o mercado doméstico, dado que o superávit de bens finais é relativamente baixo. Porém, esse padrão não é homogêneo para todos os parceiros. O perfil do comércio com a Aladi denota uma maior articulação da indústria brasileira com seus vizinhos.

Tabela 1 - Saldo comercial brasileiro relativo por etapas de produção e por parceiro comercial (2013) ${ }^{1}$

\begin{tabular}{lccccc}
\hline & Aladi & China & UE25 & $\begin{array}{c}\text { Estados } \\
\text { Unidos }\end{array}$ & Total \\
\hline Bens primários & $\mathbf{- 0 , 3 1}$ & 0,99 & 0,96 & 0,39 & $\mathbf{0 , 5 1}$ \\
Bens intermediários semiacabados & $\mathbf{0 , 0 6}$ & $-0,30$ & $-0,08$ & $-0,24$ & $\mathbf{- 0 , 1 3}$ \\
Bens intermediários partes e & $\mathbf{0 , 4 3}$ & $-0,96$ & $-0,61$ & $-0,33$ & $\mathbf{- 0 , 5 1}$ \\
componentes & $\mathbf{0 , 3 5}$ & $-0,89$ & $-0,43$ & $-0,47$ & $\mathbf{- 0 , 2 1}$ \\
Bens finais - bens de capital & $\mathbf{0 , 0 4}$ & $-0,82$ & $-0,12$ & $-0,06$ & $\mathbf{0 , 0 6}$ \\
Bens finais - bens de consumo & $\mathbf{0 , 0 9}$ & 0,10 & $-0,04$ & $-0,19$ & $\mathbf{0 , 0 0}$ \\
SALDO TOTAL & $\mathbf{0 , 1 6}$ & $-0,67$ & $-0,25$ & $-0,28$ & $\mathbf{- 0 , 1 8}$ \\
SALDO MANUFATURAS & & &
\end{tabular}

Fonte: Elaboração própria a partir de dados da United Nations Statistics Division (2019).

Nota: ${ }^{1}$ Saldo comercial relativo corresponde à razão entre o saldo comercial e a corrente de comércio $\left(S^{\prime}=(X-M) / X+M\right)$.

Conforme outros trabalhos sobre a integração produtiva entre os países da Aladi e do Mercosul (CASTILHO, 2012; COSTA, 2014), ainda que a integração produtiva regional seja baixa quando comparada com outras regiões, alguns fatores, como os menores custos de transação (devido à proximidade geográfica e cultural) e a atuação regional de empresas multinacionais na região, contribuíram para a formação de uma incipiente articulação produtiva entre esses países. Dentre os diversos parceiros, a China é o país com o qual as importações e exporta-

13 No caso da China, em 2012, partes e componentes junto com as de bens de capital representavam $47 \%$ das exportações totais e $35 \%$ das importações totais. No caso do México, para esse mesmo ano, o peso desses bens nas exportações e importações totais do país era de, respectivamente, $41 \%$ e $47 \%$. A título de comparação, em 2012, o peso desses bens nas exportações e importações brasileiras totais era de $15 \%$ e $36 \%$ respectivamente.

14 O saldo comercial é relativo, ou seja, seu valor está comparado à corrente de comércio daquele segmento. Esse indicador mostra não somente o sentido do saldo comercial como também sua magnitude relativa ao total de comércio do mesmo segmento. 
ções desses produtos são os mais assimétricos. Do lado das exportações, o peso é inferior a $5 \%$ do total de manufaturados, enquanto que, do lado das importações, a participação é uma das mais elevadas (juntamente com a Ásia). Vale chamar a atenção de que, no caso do mercado brasileiro, a China vem ganhando progressivamente mercado e conquistando espaços anteriormente ocupados pelos Estados e pela UE, sobretudo de bens de capital.

O Gráfico 5 mostra a distribuição geográfica das exportações brasileiras segundo os estágios de produção (EP). Assim como mostrado na seção anterior, o padrão de exportação brasileiro varia muito segundo os parceiros comerciais e, mais especificamente, de acordo com a região de destino. Enquanto o padrão predominante para a Aladi e a Argentina é a exportação de bens classificados no EP 4 (principalmente material de transporte, peças e acessórios da indústria automobilística), esse padrão se modifica quando se observam o mundo, a UE e os Estados Unidos, tendo em vista a predominância dos EP 1 e 2, caracterizados por recursos naturais processados e não processados. Já o padrão exportador para a China, segundo os EP, revela uma superespecialização no EP 1, caracterizado por insumos industriais não processados.

Gráfico 5 - Diferentes padrões para diferentes parceiros: a distribuição geográfica das exportações do Brasil segundo os estágios de produção em 2013 (\% total)

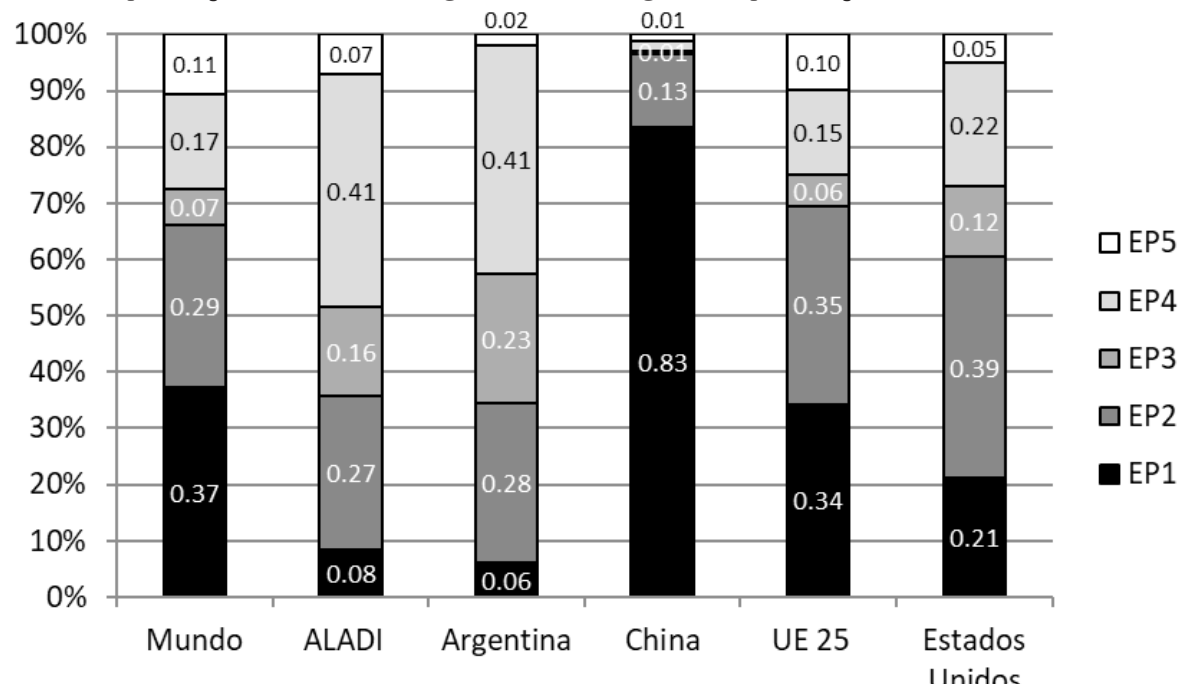

Fonte: Elaboração própria a partir de dados da United Nations Statistics Division (2019). 


\section{A Perda de Espaço do Brasil no Mercado de Produtos Manufaturados da Aladi: o Efeito da Concorrência Chinesa}

O mercado latino-americano é, como visto anteriormente, o principal mercado de destino dos produtos manufaturados brasileiros, principalmente daqueles de maior sofisticação tecnológica. É também a região com a qual a indústria brasileira tem algum tipo de articulação produtiva, importante tanto do ponto de vista da competitividade da indústria brasileira, quanto do ponto de vista da coesão dos acordos comerciais da América Latina.

O Brasil vem, no entanto, perdendo participação em seu mercado mais relevante. Na década de 1990, a integração latino-americana ganhou novo fôlego com a assinatura do Mercosul, o renascimento da Comunidade Andina e os acordos que foram alimentados por esses subacordos regionais. ${ }^{15}$ Nesse contexto, o Brasil conseguiu expandir suas vendas de produtos manufaturados para a região, tendo passado sua participação nos mercados da Aladi de 2,2\% do total para 6,4\% em 2005 (ver Tabela 2). A Aladi, por sua vez, saltou de mercado minoritário, responsável por $12 \%$ dos produtos manufaturados exportados pelo Brasil, para ser seu principal destino (a partir de 2000, sua participação seria de 27\% ou mais). Embora, para o Brasil, a Aladi tenha mantido sua colocação de principal destino das exportações de manufaturados, a parcela de mercado do Brasil na Aladi vem caindo desde 2007, chegando, em 2013, a um patamar próximo daquele observado em $2000(4,5 \%)$.

15 Pomfret (2005) periodiza os acordos comerciais regionais em três ondas de regionalismo: a) a primeira está relacionada com o estabelecimento de uma união aduaneira na Europa ocidental no final dos anos 1950; b) a segunda, que ficou conhecida como "novo regionalismo", teria tido início com o afastamento dos Estados Unidos do princípio de não discriminação do General agreement on tariffs and trade (GATT) na primeira metade da década de 1980 e culminado com as negociações para o estabelecimento do Tratado Norte-Americano de Livre Comércio (Nafta), do Mercosul e o ressurgimento da Comunidade Andina; e c) a terceira onda de acordos bilaterais teria sido aquela liderada pelos países asiáticos nos anos 2000, que conformaria a denominada Association of Southeast Asian Nations (Asean). 
Tabela 2 - Evolução do market share de produtos manufaturados do Brasil e da China na Aladi e no mercado mundial (em \%)

\begin{tabular}{lcccc}
\hline \multicolumn{5}{c}{ Aladi } \\
\hline Brasil & 1990 & 2000 & 2005 & 2013 \\
China & 2,2 & 4,2 & 6,4 & 4,5 \\
\hline & 0,8 & 2,5 & 8,3 & 18,2 \\
\hline Brasil & 1990 & Mundo & & \\
China & 0,8 & 2000 & 2005 & 2013 \\
\hline
\end{tabular}

Fonte: Elaboração própria a partir de dados da United Nations Statistics Division (2019).

A perda de mercado pelo Brasil pode ser em parte creditada à China, que aumentou de forma significativa sua participação no mercado de manufaturados da Aladi nos últimos 20 anos. Ao longo dos anos 2000, a China aumentou progressivamente seu peso como mercado de destino das exportações brasileiras, movimentando-o, que se aprofundou a partir de 2005. Essa evolução contrastou com o que ocorreu com a participação das exportações brasileiras nos mercados da Aladi, que aumentou até 2005, recuando posteriormente.

Como se pode ver na Tabela 2, o crescimento da parcela de mercado detida pela China nos países da América Latina foi muito superior ao crescimento observado para a sua participação no mercado mundial como um todo, sugerindo que a região vem se tornando um mercado de crescente importância para aquele país. Ao mesmo tempo, sugere que parte da perda de mercado do Brasil na região tem sido absorvida também pela China. Como apontam Hiratuka et al. (2012), o Brasil não é o principal perdedor nos mercados da Aladi: os resultados desse estudo mostram que as exportações chinesas para a região vêm deslocando outros fornecedores asiáticos, europeus e norte-americanos. No que se refere ao mercado doméstico brasileiro, Soares e Castilho (2014) encontram resultado similar e constatam que a maior presença chinesa deslocou principalmente fornecedores de outros países. Ambos os resultados, porém, utilizam dados de até 2009, portanto esse cenário pode ter se alterado desde então.

A perda do Brasil no mercado latino-americano parece não ter sido maior por conta das margens de preferências comerciais que gozam os produtos brasileiros no âmbito da Aladi. Os acordos da Aladi, existentes desde a década de 1980, garantem reduções para parte relevante dos produtos exportados pelo Brasil para a maioria dos países (México é o único parceiro a conceder reduções inferiores 
a 40\%) e certamente contribuíram para o desempenho exportador brasileiro no restante da América Latina desde a década de $1990 .{ }^{16}$

Porém, a vantagem obtida pelos produtos brasileiros em virtude das preferências tem perdido eficácia devido à deterioração da competitividade dos produtos brasileiros em face de determinados países (notadamente asiáticos) e devido também à erosão das preferências resultante dos múltiplos acordos comerciais que têm sido assinados pelos países latino-americanos com países externos à região. Chile, Peru, México e Colômbia já assinaram um número elevado de acordos com países de diversos continentes, notadamente com Estados Unidos, UE e China (no caso do Peru e do Chile). ${ }^{17}$ Diversos desses acordos apresentam cláusulas e concessões mais aprofundadas do que aqueles presentes nos acordos com o Brasil no âmbito da Aladi. ${ }^{18}$ Pereira (2014) atribui a queda de participação desses países nas exportações brasileiras de manufaturados (entre 2005 e 2013) à erosão das preferências brasileiras nesses mercados. Em uma avaliação da política externa do Brasil na América do Sul, Sennes (2010, p. 119) avalia que “[...] o Brasil não tem logrado estabelecer negociações mais amplas e profundas no campo comercial com os países vizinhos do que os acordos que estes países têm com terceiros [...]", o que, segundo o autor, vem promovendo uma corrosão das margens de preferências de que o Brasil se beneficiava até meados dos anos 1990 na região. ${ }^{19}$

No que se refere à concorrência chinesa no mercado da Aladi, a proposta de análise será também a partir do índice de similaridade. Contudo, neste estudo será visto sob a perspectiva do grau de sobreposição da pauta exportadora para um mesmo mercado, ou seja, estimará a concorrência, em nível de produto, entre dois países dentro de uma mesma área geográfica. Será definido da mesma maneira que antes:

$$
\mathrm{ISE}_{\mathrm{ijt}}^{\mathrm{k}}=\sum_{\mathrm{k}=1}^{\mathrm{n}} \min \left(\mathrm{s}_{\mathrm{iat}}^{\mathrm{k}} ; \mathrm{s}_{\mathrm{jat}}^{\mathrm{k}}\right)
$$

A variável $\mathrm{ISE}_{\mathrm{ijt}}^{\mathrm{k}}$ é o índice de similaridade das exportações do país i (Brasil) e do país $\mathrm{j}$ (China), no mercado a (Aladi) no tempo $t$; o termo $\mathrm{s}^{\mathrm{k}}{ }_{\text {iat }}$ revela a participação do produto $k$ na pauta de exportação do país $i$ (Brasil), no mercado a (Aladi)

16 Para mais detalhes, ver Souza (2011). Nesse estudo, Souza também mostra, por meio da estimação de uma equação gravitacional, que o comércio entre os acordos da Aladi tem impacto positivo sobre os fluxos comerciais intrarregionais.

17 De acordo com os dados da OMC, a China tem acordos comerciais firmados com três países da América Latina (Chile, Costa Rica e Peru), enquanto os Estados Unidos, que são o principal parceiro da maior parte dos países da região, possuem acordos regionais com a maior parte deles (México, Chile, Colômbia, Peru e América Central mais a República Dominicana).

18 Ortiz e Azevedo (2016), ao analisarem o potencial de comércio de Chile, Peru, México e Colômbia no âmbito da Aliança do Pacífico, apresentam os acordos comerciais firmados por esses países.

19 Tal comportamento, por usa vez, teria evitado que o Brasil fizesse concessões semelhantes aos parceiros e abrisse, assim, mão de sua margem de manobra em termos de política comercial e tarifária. 
e no tempo $t ; \mathrm{s}_{\text {jat }}^{\mathrm{k}}$ é a participação do produto $k$ na pauta de exportação do país $j$ (China), no mercado a (Aladi) para o mesmo período.

A Tabela $3^{20}$ mostra como a evolução do índice, seja para o total exportado ou para os produtos manufaturados, permaneceu relativamente estável durante os anos 2000, com maior crescimento entre os anos 2000 e 2007. O indicador revela que $25 \%$ dos produtos manufaturados exportados pelo Brasil para a Aladi são iguais aos exportados pela China para o mesmo mercado. Ambas as pautas de exportações estão concentradas no setor de fabricação de produtos de metal, máquinas e material. A principal diferença entre elas é que a China possui uma maior participação nas atividades ligadas à chamada indústria tradicional, como fabricação de couro, calçados e vestuário. Já o Brasil possui uma representatividade relativamente superior à chinesa na indústria química, como borracha e plástico. ${ }^{21}$

Tabela 3 - Índice de similaridade das exportações brasileiras e chinesas para o mercado da Aladi (2000, 2007 e 2013)

\begin{tabular}{cccc}
\hline & Total & \multicolumn{2}{c}{ Manufaturados } \\
\hline $\mathbf{2 0 0 0}$ & 0,19 & $\mathbf{2 0 0 0}$ & 0,20 \\
$\mathbf{2 0 0 7}$ & 0,25 & $\mathbf{2 0 0 7}$ & 0,26 \\
$\mathbf{2 0 1 3}$ & 0,24 & $\mathbf{2 0 1 3}$ & 0,25 \\
\hline
\end{tabular}

Fonte: Elaboração própria a partir de dados da United Nations Statistics Division (2019).

De acordo com o Banco Mundial (2013), o choque global de oferta de produtos manufaturados suavizou o crescimento potencial das exportações de manufaturas da América Latina, especificamente para aqueles países com estruturas de exportações similares às chinesas.

Para se ter uma ideia efetiva do deslocamento dos produtos brasileiros por parte da China no mercado latino-americano, a seção a seguir faz uma análise baseada na metodologia de CMS. Dessa maneira, é possível verificar quais foram as atividades que o Brasil observou perdas ou ganhos em virtude da concorrência chinesa.

20 Uma vez que o índice de similaridade é bastante sensível ao nível de agregação, utilizou-se o sistema harmonizado da Comtrade, desagregado a seis dígitos, para os anos de 2000, 2007 e 2013. Vale ressaltar que a ausência de dados desagregados ao nível do HS-6 dígitos para a China no ano de 1990 restringiu o índice para os anos 2000. Ademais, cabe observar que o índice de similaridade desagregado no HS-6 dígitos foi convertido para a international standard industrial classification (ISIC) a quatro dígitos, de modo a manter a coerência com os demais indicadores que também utilizam essa classificação.

21 Esses resultados corroboram os estudos de Carmo, Bittencourt e Raiher (2014) e Filgueiras e Kume (2010), que mostram um avanço da concorrência chinesa também nos mercados do Mercosul e dos Estados Unidos, respectivamente. Vale dizer, no entanto, que, apesar dessa maior concorrência chinesa nos mercados preferenciais do Brasil, a qualidade dos produtos exportados pelo Brasil ainda é, segundo os autores citados, superior aos exportados pela China nos mercados do Mercosul e dos Estados Unidos. Porém, a tendência é de aumento do grau de sofisticação das exportações chinesas e de distanciamento das pautas exportadoras desses dois países. 


\section{Estimativa de Ganhos e Perdas de Mercado a partir de uma Versão Mo- dificada do Modelo de Constant Market Share}

O modelo CMS permite associar as perdas de um país aos ganhos de seus competidores. Como é possível inferir, essa é uma análise estática, tendo em vista que os produtos deslocados pelos concorrentes são homogêneos. Utiliza-se essa metodologia para se verificar em que medida a perda de mercado do Brasil na América Latina nos mercados mais dinâmicos está associada ao crescimento da China.

Em sua versão original, o modelo CMS busca explicar as variações da participação de mercado (market share) das exportações de um determinado país por meio de um exercício de decomposição que identifica os seguintes efeitos: crescimento de demanda mundial, composição setorial, composição geográfica e competitividade, sendo o último termo residual. Batista e Azevedo (2002) desenvolvem um modelo de CMS que identifica quais são os países que ganham ou perdem com as variações de market share do país exportador. Essa metodologia é empregada para um mercado de destino em particular e pode, ou não, ser desagregada setorialmente. Conforme mostra-se a seguir, o exercício procura associar as perdas ou ganhos de exportações de um país j qualquer para determinada região (ou país) às perdas e ganhos de um concorrente (país g) que faz parte do conjunto de concorrentes $w$ naquele mesmo mercado.

O valor das perdas, $\mathrm{P}_{\mathrm{j}, \mathrm{i}}^{\mathrm{d}}$ (ou ganhos, $\mathrm{G}_{\mathrm{j}, \mathrm{i}}^{\mathrm{d}}$ ) das exportações do país $\mathrm{j}$ no produto $i$ em determinado mercado $d$ (país ou região) corresponde a:

$$
\mathrm{P}_{\mathrm{j}, \mathrm{i}}^{\mathrm{d}}=\left(m k s_{\mathrm{j}, \mathrm{i}}^{\mathrm{d}, \mathrm{t}}-\mathrm{mks}_{\mathrm{j}, \mathrm{i}}^{\mathrm{d}, \mathrm{t}-1}\right) \times \mathrm{M}_{\mathrm{i}}^{\mathrm{d}, \mathrm{t}}
$$

em que $\mathrm{mks}_{\mathrm{j}, \mathrm{i}}^{\mathrm{d}, \mathrm{i}}$ é o market share do país j do produto $i$ no mercado $d$ para o período t e $\mathrm{M}^{\mathrm{d}, \mathrm{t}}{ }_{\mathrm{i}}$ corresponde às importações do produto $i$ do país $d$ para o período $t$. Se $\mathrm{mks}^{\mathrm{d}, \mathrm{t}-\mathrm{i}}{ }_{\mathrm{j}, \mathrm{i}}>\mathrm{mks}_{\mathrm{j}, \mathrm{i}}^{\mathrm{d}, \mathrm{t}}$, o país $\mathrm{j}$ perdeu marke share naquele mercado entre os anos $t-1$ e $t$.

Uma vez calculadas as perdas e os ganhos de cada um dos parceiros selecionados para determinado produto $i$, entre dois períodos, pode-se associar as perdas (ou ganhos) do país exportador às variações de participação dos concorrentes (para um país g qualquer) para o produto $i$ e no mesmo mercado de destino. Para isso, multiplicam-se as perdas de mercado do país pela proporção dos ganhos do país naquele mercado:

$$
P_{j, g, i}^{d}=P_{j, i}^{d} \times\left[\frac{\left(m k s_{g, i}^{t}-m k s_{g, i}^{t-1}\right)}{\sum_{w=1}\left(m k s_{w, i}^{t}-m k s_{w, i}^{t-1}\right)}\right]
$$

O primeiro termo do lado direito $\left(\mathrm{P}_{\mathrm{j}, \mathrm{i}}^{\mathrm{d}}\right)$ corresponde à perda de participação do país j no mercado em questão. O segundo termo corresponde à participação 
do país concorrente g no total de ganhos de todos os países $(w)$ que ganharam mercado no país (ou região) em análise. Pode-se calcular a perda bruta total de um país $d$ atribuída a um país g por meio da agregação de todos os produtos para os quais o país $d$ perdeu mercado, assim como de todos os produtos em que o país g ganhou participação.

Busca-se identificar qual parcela dos ganhos e perdas do Brasil no mercado latino-americano está associada à China e a outros parceiros comerciais. Para se realizar esse exercício, utilizam-se os dados de importações da Aladi provenientes do Brasil, além das importações provenientes da própria região, da UE, da China, dos Estados Unidos e do resto do mundo desagregados a quatro dígitos da industrial standart international classification (ISIC), revisão dois. O período analisado está compreendido entre os anos 2000 e 2013, porém esse intervalo será subdividido em dois subperíodos (2000 a 2007 e 2007 a 2013), em virtude da evolução do comércio dos países latino-americanos com a China, que se intensificou de forma expressiva nos últimos anos.

O Gráfico 6 mostra as exportações brasileiras de produtos manufaturados para a Aladi ao longo dos anos 2000. Os dados para o Brasil revelam que os ganhos obtidos no período de 2000 a 2007 (cerca de US\$ 10 bilhões) foram revertidos entre 2007 e 2013. O comércio intraAladi apresentou evolução semelhante: ganhos líquidos no primeiro subperíodo e perdas líquidas entre 2007 e 2013 (superiores aos ganhos anteriores). A UE apresentou pequena perda de mercado no primeiro subperíodo, que foi compensada pelos ganhos observados no segundo subperíodo. Chama atenção a perda de mercado dos Estados Unidos que ocorre ao longo de todo o período, apesar de bem mais intensa entre 2000 e 2007. Por sua vez, a China mostrou evolução com ganhos significativos nos dois subperíodos, conforme mostrado anteriormente. O Gráfico 6 mostra uma diversificação da pauta de comércio da Aladi com a perda de importância de um parceiro histórico da região (Estados Unidos) e um aumento do intercâmbio com a Ásia, notadamente a China. ${ }^{22}$

22 Lucángeli (2016) atribui o baixo crescimento das importações de produtos manufaturados dos Estados Unidos pelos países sul-americanos entre 2000 e 2011 à maior concorrência chinesa na região. 
Gráfico 6 - Perdas e ganhos de países selecionados no mercado de produtos manufaturados da Aladi (2000 a 2013): em US $\$$ bilhões

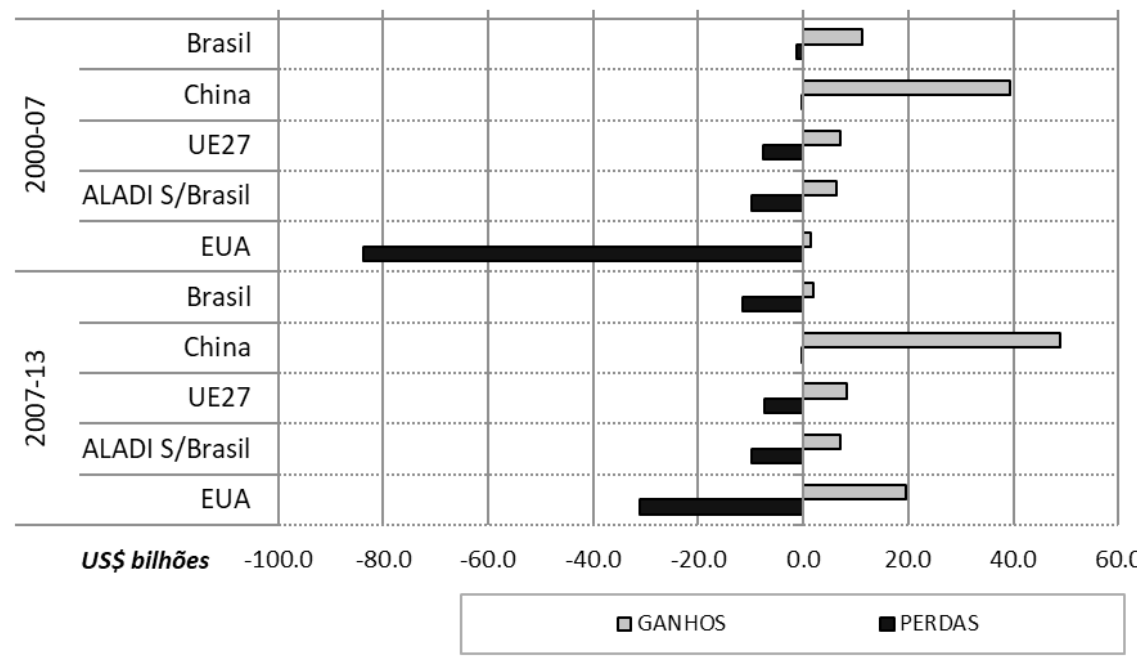

Fonte: Elaboração própria a partir de dados da United Nations Statistics Division (2019).

A análise detalhada sob o ponto de vista dos ganhos e perdas permite associar as perdas brasileiras a ganhos de mercado dos demais parceiros. Os resultados sugerem que as perdas de mercado do Brasil na Aladi correspondem, em grande parte, a ganhos para a China. Ou seja, na maior parte dos produtos nos quais o Brasil perdeu market share, o principal país ganhador de mercado foi a China. A Tabela 4 mostra que, entre 2000 e 2007, 43\% das perdas brasileiras estiveram associadas a ganhos da China. Já entre 2007 e 2013, não somente esse percentual cresceu para $62 \%$, como também, em termos de valor, houve um crescimento significativo. Ou seja, as perdas de mercado do Brasil na Aladi aumentaram ao longo do período e a parte associada à China é crescente. A perda do Brasil para a UE e para os Estados Unidos é insignificante nos dois subperíodos, sendo que apenas no primeiro subperíodo algumas perdas parecem estar associadas com as exportações intrarregionais da Aladi. 
Tabela 4 - Perdas dos produtos manufaturados do Brasil na Aladi atribuídas a países selecionados (em \% do total de perdas e ganhos de cada país e US\$ em bilhões)

\begin{tabular}{lccccc}
\hline $\begin{array}{c}\text { Perdas de mercado do } \\
\text { Brasil na Aladi }\end{array}$ & \multicolumn{1}{c}{$\begin{array}{c}\mathbf{2 0 0 0 - 0 7} \\
\text { US\$ bi }\end{array}$} & \% & US\$ bi & \% \\
\hline TOTAL & $(1.314,74)$ & - & $(11.495,15)$ & - \\
Atribuídas à... & & & & \\
& ...China & $(564,78)$ & 43 & $(7.158,61)$ & 62 \\
& ...UE-25 & $(65,71)$ & 5 & $(1.624,65)$ & 14 \\
& ...Aladi & $(372,13)$ & 28 & $(426,60)$ & 4 \\
...Estados Unidos & $(79,60)$ & 6 & $(915,85)$ & 8 \\
\hline
\end{tabular}

Fonte: Elaboração própria a partir de dados da United Nations Statistics Division (2019).

De uma forma geral, as principais perdas de mercado do Brasil para a China no mercado da Aladi, em termos setoriais (ver Tabela 5), ocorreram nos setores de metal, máquinas e material de transporte. Nesses setores estão localizados produtos de maior sofisticação e com algum grau de articulação produtiva entre os países latino-americanos. Considerando-se a importância que essas atividades possuem para a pauta exportadora brasileira, a concorrência com a China nesse segmento certamente terá consequências futuras para a estrutura produtiva doméstica. Na análise para outros setores, a concorrência chinesa deslocou também produtos da indústria têxtil durante o intervalo de 2000 a 2007. 
Tabela 5 - Distribuição setorial das perdas dos produtos manufaturados do Brasil na Aladi atribuídas à China (em \% do total)

\begin{tabular}{lcc}
\hline ISIC revisão 2 & $\mathbf{2 0 0 0 - 2 0 0 7}$ & $\mathbf{2 0 0 7 - 2 0 1 3}$ \\
\hline Produtos alimentares, bebidas e fumo & 4,9 & 0,2 \\
Têxtil, vestuário e indústria de couro & 21,0 & 5,6 \\
Indústria de madeira (inclusive móveis) & 2,2 & 0,9 \\
Indústria de papel e seus artigos, impressão e edição & - & 0,3 \\
Indústria química, derivados de petróleo, borracha e & & \\
plástico & 2,2 & 11,2 \\
Fabricação de produtos minerais não metálicos & 1,7 & 1,4 \\
Indústria metalúrgica de base & - & 13,3 \\
Produção de metal, máquinas e material de transporte & 66,5 & 66,9 \\
Outras indústrias manufatureiras & 1,6 & 0,2 \\
\hline Total & 100,0 & 100,0 \\
\hline
\end{tabular}

Fonte: Elaboração própria a partir de dados da United Nations Statistics Division (2019).

\section{Considerações Finais}

O mercado latino-americano é o principal mercado dos produtos manufaturados brasileiros, sobretudo aqueles de maior sofisticação. É também a região com a qual a indústria brasileira tem algum tipo de articulação produtiva, o que é relevante tanto do ponto de vista da competitividade da indústria nacional quanto do ponto de vista da coesão dos acordos de integração na América Latina.

A emergência das cadeias regionais e globais de produção afetou a natureza da competição internacional e renovou o debate acerca da importância da integração regional para uma melhor inserção internacional dos países. Os resultados obtidos no presente estudo sugerem que o padrão de especialização comercial do Brasil tem posicionado o país nas etapas menos dinâmicas do comércio internacional, hoje caracterizado pelo aprofundamento da fragmentação produtiva. O país tem se localizado predominantemente como fornecedor nas etapas iniciais dos processos produtivos - a única exceção se dá no intercâmbio com a Aladi. Esse comércio é fortemente influenciado pelos fluxos bilaterais de veículos automotores entre Brasil e Argentina.

O Brasil vem, no entanto, perdendo participação em seu mercado de bens manufaturados mais relevantes. É verdade que os produtos manufaturados brasileiros perderam espaço também nos mercados mais tradicionais da UE e dos Estados Unidos. Nos anos 90, a integração latino-americana ganhou novo fôlego com o surgimento do Mercosul, o renascimento da Comunidade Andina e os acordos que foram alimentados por esses subacordos regionais. Nesse contexto, 
o Brasil conseguiu expandir suas vendas de produtos manufaturados na região, triplicando sua participação nos mercados da Aladi entre 1990 e 2005. Por sua vez, a Aladi passou de mercado secundário para os manufaturados brasileiros para seu principal destino (a partir de 2000, sua participação passa de 20\% e atinge 34\% das exportações brasileiras em 2013). Isso se deve ao aprofundamento dos acordos regionais nos anos 1990. Nos anos 2000, apesar da Aladi ter se mantido como principal destino das exportações de manufaturados, os produtos manufaturados brasileiros perderam mercado desde 2007, chegando, em 2013, a um patamar próximo ao observado em 2000.

A perda de mercado pelo Brasil pode ser, em parte, creditada à China, que viu sua participação no mercado de manufaturados da Aladi crescer de forma significativa desde os anos 1990 até se tornar o principal parceiro externo da região, deslocando, inclusive, o principal parceiro dos países da região - os Estados Unidos. Tal tendência se intensificou a partir de 2005 e, em particular, após a crise de 2008. O avanço dos produtos chineses foi, em parte, em prejuízo de terceiros países. Porém, o descompasso entre as taxas de crescimento do market share brasileiro e chinês na região, assim como o grau de competição revelado pela evolução da similaridade da pauta exportadora dos dois países sugere que parte do mercado do Brasil na região tem sido absorvida por aquele país. As estimativas de perdas e ganhos do Brasil e da China no mercado da Aladi por meio do modelo de CMS modificado confirmam tal impressão, associando $60 \%$ das perdas incorridas pelo Brasil entre 2000 e 2013 a ganhos da China. Esse movimento se acentuou a partir de 2007 e parece afetar, em particular, os setores de máquinas, equipamentos e material de transporte. Vale assinalar que esses setores não somente figuram entre aqueles de maior sofisticação, mas também são aqueles nos quais existe algum grau de articulação produtiva entre os países latino-americanos.

Acrescenta-se a esse cenário, caracterizado pela perda de competitividade dos produtos manufaturados brasileiros, a erosão das preferências comerciais desfrutadas pelo país na região. Tal erosão resulta dos múltiplos acordos comerciais que têm sido assinados pelos países latino-americanos com países externos à região. Tais acordos acabam por corroer as vantagens tarifárias obtidas pelos produtos brasileiros nos mercados latino-americanos, muitas vezes beneficiando produtos provenientes de países com alta capacidade competitiva, como China e Coreia do Sul.

A reversão dessa tendência claramente negativa para as exportações brasileiras de manufaturados depende, dentre outros fatores, de uma melhora na competitividade dos produtos brasileiros e de iniciativas que estimulem o comércio regional. Essas iniciativas devem possibilitar o aprofundamento dos acordos com os vizinhos latino-americanos dentro de uma estratégia mais ampla de articulação produtiva na região, que obrigatoriamente vai além da esfera estritamente comer- 
cial e que geraria benefícios não somente para a indústria brasileira, mas também para os seus vizinhos latino-americanos.

\section{Referências}

BALDWIN, R. Global supply chains: why they emerged, why they matter, and where they are going. London: Centre for Economic Policy Research, 2012. (CEPR Discussion Paper n. 9103, Aug. 2012). Disponível em: < https://cepr.org/active/publications/discussion_papers/ dp.php?dpno=9103\#> . Acesso em: 20 mar. 2019.

BATISTA, J. C.; AZEVEDO, J. P. W. El TLC y las pérdidas de mercado de Brasil en los Estados Unidos: 1992-2001. Revista de la Cepal, n. 78, p. 167-182, dic. 2002. Disponível em: <https:// repositorio.cepal.org/bitstream/handle/11362/10858/1/078167182_es.pdf > . Acesso em: 20 mar. 2019.

BAUMANN, R. O Mercosul aos vinte anos: uma avaliação econômica. Brasília: Ipea, 2011. (Texto para Discussão n. 1627, jun. 2011). Disponível em: <http://repositorio.ipea.gov.br/ bitstream/11058/1493/1/td_1627.pdf>. Acesso em: 20 mar. 2019.

. Regional trade and growth in Asia and Latin America: the importance of productive complementarity. Brasília: Economic Commission for Latin America and the Caribbean/Office in Brazil, 2010. (Textos para Discussão Cepal/Ipea n. 16, nov. 2010). Disponível em: <https://repositorio.cepal.org/bitstream/handle/11362/3145/LCbrsR238_ en.pdf? sequence $=1$ EisAllowed $=\mathrm{y}>$. Acesso em: 20 mar. 2019.

BRASIL. Ministério do Desenvolvimento, Indústria e Comércio Exterior. Secretaria de Comércio Exterior. Estatísticas de Comércio Exterior. Disponível em: <http://www.mdic.gov. br/index.php/comercio-exterior/estatisticas-de-comercio-exterior $>$. Acesso em: 20 mar. 2019.

CARMO, A. S. S.; BITTENCOURT, M. V. L.; RAIHER, A. P. A competitividade das exportações do Brasil e da China para o Mercosul: evidências para o período 1995-2009. Nova Economia, Belo Horizonte, v. 24, n. 3, p. 587-607, set./dez. 2014. Disponível em: < https://revistas.face. ufmg.br/index.php/novaeconomia/article/view/1860/1477> . Acesso em: 20 mar. 2019.

CARNEIRO, R. M. Commodities, choques externos e crescimento: reflexões sobre a América Latina. Santiago, Chile: Cepal / Naciones Unidas, 2012. (Cepal - Serie macroeconomía del desarrollo, n. 117, 2012). Disponível em: <https://repositorio.cepal.org/bitstream/ handle/11362/5349/1/S1100893_pt.pdf >. Acesso em: 20 mar. 2019.

CASTILHO, M. Comércio internacional e integração produtiva: uma análise dos fluxos comerciais dos países da Aladi. Brasília, DF: Ipea, 2012. (Texto para discussão n. 1705, jan. 2012). Disponível em: <http://www.ipea.gov.br/portal/images/stories/PDFs/TDs/td_1705. pdf > . Acesso em: 20 mar. 2019.

. Exportações brasileiras de bens manufaturados e integração regional: evolução

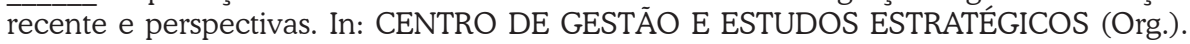
Dimensões estratégicas do desenvolvimento brasileiro: Brasil: em busca de um novo modelo de desenvolvimento. Brasília, DF: Centro de Gestão e Estudos Estratégicos, 2015. v. 4. p. 259-277. Disponível em: < https://www.cgee.org.br/documents/10195/734063/CS6_CAEBS_ 
v4_LIVRO_17022016_10256.pdf/3064f552-60c0-4ea9-9877-4a7f8fa4a4d9?version=1.2 > . Acesso em: 20 mar. 2019.

. Impactos da crise econômica internacional sobre o comércio exterior brasileiro. In: ACIOLY, L.; LEÃO, R. P. F. (Org.). Crise financeira global: mudanças estruturais e impactos sobre os emergentes e o Brasil. Brasília: Ipea, 2011. v. 2. p. 97-127. Disponível em: <http:// www.ipea.gov.br/portal/images/stories/PDFs/livros/livros/livro_crisefinanceira.pdf>. Acesso em: 20 mar. 2019.

CHEN, L.; LOMBAERDE, P. Redes de distribución regional de la producción y organización en ejes en América Latina y en el Este asiático: una perspectiva a largo plazo. Integración E Comercio, Buenos Aires, v. 15, n. 32, p. 21-39, enero/jun. 2011. Disponível em: < https:// www.researchgate.net/publication/260157140_Redes_de_distribucion_regional_de_la_ produccion_y_organizacion_en_ejes_en_America_Latina_y_en_el_Este_Asiatico_una_

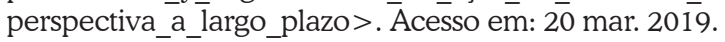

COMISIÓN ECONÓMICA PARA AMÉRICA LATINA Y EL CARIBE. Panorama de la inserción internacional de América Latina y el Caribe: integración regional y cadenas de valor en un escenario externo desafiante. Santiago de Chile: Cepal; Naciones Unidas, 2014. Disponível em: <http://ibce.org.bo/images/publicaciones/Panorama-Insercion-Internacional-AmericaLatina-Caribe-2014.pdf> . Acesso em: 20 mar. 2019.

COSTA, K. G. V. Fragmentação internacional da produção e sofisticação das exportações: uma análise a partir dos fluxos de comércio do Mercosul entre 1994 e 2012. In: ENCONTRO NACIONAL DE ECONOMIA, 42., 2014, Natal. Anais... Natal: Anpec, 2014. Disponível em: $<$ https:/www.anpec.org.br/encontro/2014/submissao/files_I/i7-e8f74719a28febf555f13e059 90eb312.pdf > . Acesso em: 20 mar. 2019.

CUNHA, A. M. et al. A intensidade tecnológica das exportações brasileiras no ciclo recente de alta nos preços das commodities. Indicadores Econômicos FEE, Porto Alegre, v. 39, p. 4770, 2011.

FEENSTRA, R. C. Integration of trade and disintegration of production in the global economy. Journal of Economic Perspectives, v. 12, n. 4, p.31-50, 1998. Disponível em: <http:// citeseerx.ist.psu.edu/viewdoc/download?doi=10.1.1.39.7178\& $\mathrm{rep}=$ rep 1 \&type $=\mathrm{pdf}>$. Acesso em: 20 mar. 2019.

FILGUEIRAS, M.; KUME, H. A competitividade do Brasil e da China no mercado norteamericano: 2000-2008. Brasília: Ipea, 2010. (Texto para discussão n. 1501, jul. 2010). Disponível em: <http://www.ipea.gov.br/portal/images/stories/PDFs/TDs/td_1501.pdf>. Acesso em: 20 mar. 2019.

FINGER, J. M.; KREININ, M. E. A measure of 'export similarity' and its possible uses. The Economic Journal, v. 89, n. 356, p. 905-912, Dec. 1979. Disponível em: <https:/www.jstor. org/stable/2231506?seq=1\#page_scan_tab_contents >. Acesso em: 20 mar. 2019.

FLORES, M.; VAILLANT, M. Cadenas globales de valor y sofisticación de la canasta de exportación en América Latina. Integración 8 Comercio, Buenos Aires, v. 15, n. 32, p. 45-58, enero-jun. 2011. Disponível em: <https://ideas.repec.org/p/ude/wpaper/0811.html > . Acesso em: 20 mar. 2019. 
FONTAGNÉ, L.; FREUDENBERG M.; ÜNAL-KESENCI D. Statistical analysis of EC trade in intermediate products. Paris: Eurostat, 1996. Disponível em: <http://aei.pitt.edu/67874/1/10. pdf>. Acesso em: 20 mar. 2019.

GUIMARÃES, E. A. et al. Índices de rentabilidade das exportações brasileiras: atualização 2010. Rio de Janeiro: Fundação Centro de Estudos do Comércio Exterior, 2010. (Texto para discussão, n. 194, jun. 2010). Disponível em: <http://www.funcex.org.br/publicacoes/tds/ TDFUNCEX194.pdf>. Acesso em: 20 mar. 2019.

HAMAGUCHI, N. Integração produtiva regional no leste da Ásia. In: ALVAREZ, R.; BAUMANN, R.; WOHLERS, M. (Org.). Integração produtiva: caminhos para o Mercosul. Brasília, DF: ABDI, 2010. p. 304-343.

HIRATUKA, C. et al. Avaliação da competição comercial chinesa em terceiros mercados. In: BITTENCOURT, G. (Org.). El impacto de China en América Latina: comercio e inversiones. Montevidéu: Red Mercosur, 2012. v. 1. p. 135-194.

INSTITUTO DE PESQUISA ECONÔMICA APLICADA. Ipeadata. Disponível em: < http:// www.ipeadata.gov.br/Default.aspx:. Acesso em: 25 mar. 2019.

KUPFER, D. et al. Different partners, different patterns: trade and labour market dynamics in Brazil's post-liberalisation period. [S. 1.]: Organisation for Economic Cooperation and Development, 2013. (OECD Trade Policy Papers, n. 149, 2013). Disponível em: <https:// www.oecd-ilibrary.org/docserver/5k480c265kq1-en.pdf?expires $=1551593705 \mathcal{E}$ id $=$ id\&3accn ame $=$ guestE 3 checksum $=256$ D6D042BD46FEA96325566202C5037>. Acesso em: 20 mar. 2019.

LEMOINE, F.; ÜNAL-KESENCI, D. China in the international segmentation of production processes. [S. 1.]: Centre d'Etudes Prospectives et d'Informations Internationales, 2002. (CEPPII Working Paper, n. 02, Mar. 2002). Disponível em: <http://www.cepii.fr/PDF_PUB/ wp/2002/wp2002-02.pdf>. Acesso em: 20 mar.2019.

LUCÁNGELI, J. Las exportaciones extra-regionales de manufacturas de los países sudamericanos. [S. 1.]: Banco Interamericano de Desarrollo, 2016. Disponível em: <https:// publications.iadb.org/en/publication/15598/las-exportaciones-extra-regionales-demanufacturas-de-los-paises-sudamericanos> . Acesso em: 20 mar. 2019.

MEDEIROS, C. Integração produtiva: a experiência asiática e algumas referências para o Mercosul. In: ALVAREZ, R.; BAUMANN, R.; WOHLERS, M. (Org.). Integração produtiva: caminhos para o Mercosul. Brasília: ABDI, 2010. p. 252-303.

MENG, B.; FANG, Y.; YAMANO, N. Measuring global value chains and regional economic integration: an international input-output approach. Chiba, Japan: Institute of Developing Economies Japan External Trade Organization, 2012. (Discussion Papers, n. 362, 2012). Disponível em: <https://www.ide.go.jp/English/Publish/Download/Dp/362.html > . Acesso em: 20 mar. 2019.

MILBERG, W. The changing structure of trade linked to global production systems: what are the policy implications? International Labour Review, v. 143, n. 1-2, p. 45-90, 2004. Disponível em: <https://onlinelibrary.wiley.com/doi/epdf/10.1111/j.1564-913X.2004.tb00546.x>. Acesso em: 20 mar. 2019. 
MILBERG, W.; WINKLER, D. Outsourcing economics: global value chains in capitalist development. Cambridge: Cambridge University Press, 2013.

MORCEIRO, P. C. Desindustrialização na economia brasileira no período 2000-2011: abordagens e indicadores. São Paulo: Cultura Acadêmica, 2012.

OREIRO, J. L.; FEIJÓ, C. A. Desindustrialização: conceituação, causas, efeitos e o caso brasileiro. Revista de Economia Política, São Paulo, v. 30, n. 2, p. 219-232, abr./jun. 2010. Disponível em: <http://www.scielo.br/pdf/rep/v30n2/03.pdf> . Acesso em: 20 mar. 2019.

ORTIZ, P. C.; AZEVEDO, A. Aliança do Pacífico: uma visão do bloco através do modelo gravitacional. In: ENCONTRO DE ECONOMIA DA REGIÃO SUL, 19., 2016, Florianópolis. Anais... Florianópolis: Anpec, 2016 Disponível em: < https:/www.anpec.org.br/sul/2016/ submissao/files_I/i5-ad1f148adb3de04ec6877d1ee1a54737.pdf>. Acesso em: 20 mar. 2019.

PALMA, G. Four sources of de-industrialization and a new concept of the Dutch disease. In: OCAMPO, J. A. (Ed.). Beyond reforms: structural dynamics and macroeconomic vulnerability. Stanford: Stanford University Press, 2005. p. 71 -116.

PEREIRA, L. V. As exportações de manufaturas brasileiras e os acordos comerciais. In: BARBOSA, N. et al. (Org.). Indústria e desenvolvimento produtivo no Brasil. Rio de Janeiro: Elsevier-FGV, 2015. p. 230-250.

. O mercado das exportações de manufaturas e acordos comerciais. Conjuntura Econômica, Rio de Janeiro, v. 68, n. 1, p. 40-43, jan. 2014. Disponível em: <http:// bibliotecadigital.fgv.br/ojs/index.php/rce/article/view/19771/18494>. Acesso em: 20 mar. 2019 .

PÉREZ, C. Una visión para América Latina: dinamismo tecnológico e inclusión social mediante una estrategia basada en los recursos naturales. Revista Econômica, Niterói, v. 14, n. 2, p. 11-54, dez. 2012. Disponível em: < http:/www.revistaeconomica.uff.br/index.php/ revistaeconomica/article/view/42/48 > . Acesso em: 20 mar. 2019.

POMFRET, R. Regional trade agreements. Adelaide, Australia: University of Adelaide, 2005. (School of Economics, Working Paper, n. 2005-15, Oct. 2005). Disponível em: <https://core. ac.uk/download/pdf/6414586.pdf> . Acesso em: 20 mar. 2019.

ROCHA, F. Comentários a "Una visión para América Latina: dinamismo tecnológico e inclusión social mediante una estrategia basada en los recursos naturales", de Carlota Perez: a Lei de Engel. Revista Econômica, Niterói, v. 14, n. 2, p. 63-72, dez. 2012. Disponível em: <http://www.revistaeconomica.uff.br/index.php/revistaeconomica/article/view/44/49>. Acesso em: 20 mar. 2019.

SENNES, R. Brasil na América do Sul: internacionalização da economia, acordos seletivos e estratégia de hub-and-spokes. Revista Tempo do Mundo, Brasília, DF, v. 2, n. 3, p. 113-145, dez. 2010. Disponível em: <http://repositorio.ipea.gov.br/bitstream/11058/6243/1/RTM_v2_ n3_Brasil.pdf>. Acesso em: 20 mar. 2019.

SERRANO, F. A mudança na tendência dos preços das commodities nos anos 2000: aspectos estruturais. Oikos, Rio de Janeiro, v. 12, n. 2, p. 168-198, 2013. Disponível em: < http://www. revistaoikos.org/seer/index.php/oikos/article/viewArticle/345 > . Acesso em: 20 mar. 2019. 
SILVA, O. M.; BATISTA, J. S.; DRUMOND, R. R. BRICS: conteúdo de renda e dis(similaridade) das exportações. Revista Economia Ensaios, Uberlândia, v. 25, n. 2, p. 7-22, jan./jun. 2011. Disponível em: <http:/www.seer.ufu.br/index.php/revistaeconomiaensaios/article/ view/17296>. Acesso em: 20 mar. 2019.

SOARES, E. C. M.; CASTILHO, M. R. O impacto das importações chinesas na indústria brasileira nos anos 2000. In: ENCONTRO NACIONAL DE ECONOMIA, 42., 2014, Natal. Anais. Disponível em: < https://www.anpec.org.br/encontro/2014/submissao/files_I/i9-acc8b 9f95790afc4c7a1bd05c2df05a0.pdf>. Acesso em: 20 mar. 2019.

SOUZA, K. S. G. Os efeitos da integração comercial sobre os fluxos comerciais dos países membros da Aladi. 2011. 110 f. Dissertação (Mestrado em Economia) - Universidade Federal Fluminense, Niterói, 2011. Disponível em: < http:/www.ppge.uff.br/images/ dissertaestese/2011-Karla_Sarmento_dissert_pdf > . Acesso em: 20 mar. 2019.

STURGEON, T. J.; MEMEDOVIC, O. Mapping global value chains: intermediate goods trade and structural change in the world economy. Vienna: United Nations Industrial Development Organization, 2010. (Development Policy and Strategic Research Branch, Working Paper n. 05/2010). Disponível em: < https://www.unido.org/api/opentext/documents/ download/9928658/unido-file-9928658 > . Acesso em: 20 mar. 2019.

TORRE, A. et al. América Latina y el ascenso del Sur: nuevas prioridades en un mundo cambiante. Washington, DC: Banco Internacional de Reconstrucción y Fomento / Banco Mundial, 2015. Disponível em: <http://documentos.bancomundial.org/curated/ es/171161468184779391/pdf/96467-PUB-v2-SPANISH-9781464803567-9781464804328Overview-OUO9-Box391436B.pdf> . Acesso em: 20 mar. 2019.

UNITED NATIONS CONFERENCE ON TRADE AND DEVELOPMENT. Global value chains and development: investment and value added trade in the global economy. Genebra, 2013. Disponível em: <https://unctad.org/en/PublicationsLibrary/diae2013d1_en.pdf > . Acesso em: 20 mar. 2019.

UNITED NATIONS STATISTICS DIVISION. UN Comtrade. Disponível em: < https://wits. worldbank.org/default.aspx?lang=es > . Acesso em: 20 mar. 2019.

VEIGA, P. M.; RIOS, S. P. Cadeias de valor baseadas em recursos naturais e upgrading de empresas e setores: o caso da América do Sul. Rio de Janeiro: Cindes, 2008.

VERÍSSIMO, M. P.; XAVIER, C. L. Tipos de commodities, taxa de câmbio e crescimento econômico: evidências da maldição dos recursos naturais para o Brasil. Revista de Economia Contemporânea, Rio de Janeiro, v. 18, n. 2, p. 267-295, maio/ago. 2014. Disponível em: < http://www.scielo.br/pdf/rec/v18n2/1415-9848-rec-18-02-00267.pdf> . Acesso em: 20 mar. 2019.

WOLRD BANK. Capital for the Future: Saving and Investment in an Interdependent World. World Bank: Washington, DC, 2013. Disponível em: < https://siteresources.worldbank.org/ extdecprospects/Resources/476882-1368197310537/CapitalForTheFuture.pdf> . Acesso em: 25 mar. 2019.

WORLD TRADE ORGANIZATION. Regional Trade Agreements Information System. Disponível em: <http://rtais.wto.org/UI/PublicMaintainRTAHome.aspx> . Acesso em: 20 jul. 2016. 
WHITTAKER, D. H. et al. Compressed development. Studies in Comparative International Development, v. 45, n. 4, p. 439-467, 2010. Disponível em: <https://www.researchgate.net/ publication/227329184_Compressed_Development>. Acesso em: 20 mar. 2019.

Recebido em: 23/09/2016. Aceito em: 11/09/2017. 